\title{
Applying Reporting of Comprehensive Income in China
}

\author{
Xiaoyan Liu \\ School of Business Administration, North China Electric Power University \\ Beijing 110026, China \\ E-mail: 1liu716@sina.com \\ Yunan Liu \\ Alfred Lerner College of Business \& Economics, University of Delaware \\ Newark, DE, U.S. \\ E-mail: alluersokar@163.net
}

\begin{abstract}
This paper discusses the characteristics of comprehensive income and how to apply reporting of comprehensive income in China. Through a detailed analysis, we summarize the situation of current performance reporting type, and give some advices on how to apply comprehensive income reporting in China, to provide investors and creditors more comprehensive and relevant performance information. There are two steps advised to be applied in China to update the current income reporting to comprehensive income reporting.
\end{abstract}

Keywords: Comprehensive income, Net income, Assets-liabilities perspective, FASB

\section{Background of comprehensive income theory}

According to the traditional income perspective, the income is the difference between revenue realized in transactions and related historical cost occurred in a designated period of time, based on the accrual basis, realization principle and matching principle. It has been widely used in accounting on account of highly reliability and verifiability, which have been demonstrated by lots of empirical studies.

However, with the rapid development of economic situation, especially due to a variety of financial derivatives generation, multinational companies emerging, science and technology exploring, business activities are increasing complexity, making the principle of realization too conservative to evaluate companies' operation performances, and the historical cost not be able to demonstrate the nature of property assets. Furthermore, the shortcomings of traditional income perspective are getting more and more apparent: it omitted the effect on the income from some items such as inflation, goodwill, holding gains and their value change, let alone the measurement and disclosure of soft assets such as human resource cost and knowledge capital. Since the 1970s, with the rapid development of finance market and the quickly liquidity of global capital, the timely reporting and disclosure of income information is getting more and more important and emergent.

Because the usefulness of traditional income theory is limited to report income which has already realized, in another word, it is a kind of after event reporting, rather than during-event and not future oriented reporting. To some extent it can not meet the requirement occurred in the rapid development economy nowadays. Under the mew circumstances, a new accounting income perspective----comprehensive income perspective, which can resolve the questions above, was brought into people's eyesight and is applied in some countries. Although with the application of comprehensive income reporting, relevance is increased, on the other hand reliability is to some degree decreased.

The information provided by reporting of comprehensive income would assist investors, creditors, and other financial statement users in assessing an enterprise's economic activities and its timing and magnitude of future cash flows.

In this paper, we first discuss the characteristics of comprehensive income and worldwide application of it; and then analyze the current performance reporting situation sys in China, finally some advices on how to apply comprehensive income reporting in China is summarized 


\section{Application of reporting of comprehensive income}

\subsection{Characteristics of comprehensive income}

According to SFAS 3 of Financial Accounting Standards Board (FASB), the main content of comprehensive income perspective is to use the fair value measurement on assets and liabilities at the measurement date instead of historical cost, thus market value change of assets and liabilities: both realized income (net income) and unrealized holding gains or losses (other comprehensive income) will be included in a single comprehensive income statement.

And according to SFAS 130, "other comprehensive income" (OCI) is part of total comprehensive income but generally excluded from net income. Prior to SFAS 130, these three items-foreign currency translation adjustments, minimum pension liability adjustments, and unrealized gains or losses on available-for-sale investments-were disclosed as separate components of stockholders' equity on the balance sheet. Under SFAS 130, they are to be reported as OCI. Furthermore, they must be reported separately, as FASB decided that information about each component is more important than information about the aggregate.

Compared with the traditional income perspective, comprehensive income perspective is characterized in the following aspects:

(1) The contents covered by Comprehensive income are more extensive. Comprehensive income includes all changes of owners' equity in a designated period of time rather than additional investments by owners and distributions to owners. It consists two parts: net income -the income number of the traditional income view, and other comprehensive income, which is not included in the traditional income statement. This kind of view updates the proceeding income realization principle by reflecting the equity changes of all kinds of related business transactions, events and situations, and therefore is called comprehensive income. It not only includes income from major operating activities and realized income, but also includes other gains or losses recognized but not realized caused by other events such as market price or economic circumstances changes, which are not reflected by the traditional income view. From this meaning, it can comprehensively describe the changes on equity.

(2) The basis of comprehensive income view is assets-liabilities perspective instead of revenues-expenses perspective. Comprehensive income applies asset-liabilities perspective to recognize income, compared with revenues -expenses perspective view applied in traditional income. According to comprehensive income view, income is decided on the basis of measurement of assets and liabilities, which includes value changes of all assets and liabilities: both the income realized and gains or losses not realized.

(3) The measurement attribute is not only limited to historical cost. Under comprehensive income perspective, both historical cost and market price are adopted in the measurement of income accounting, different from the traditional income view, under which only historical cost is used. That is, assets and liabilities related to revenues and gains are measured with current prices, at the same time assets consumed or value changes related to expenses and losses are measured at either historical costs or current prices.

\subsection{Worldwide application of reporting of comprehensive income}

In December 1984, SFAS 5 insisted that the reporting of comprehensive income should be one part of a complete set of financial statement. In 1997, SFAS 130 "Reporting of Comprehensive Income" was formally released, according to which, comprehensive income consists two parts: net income and other comprehensive income.

In June 1991, a research team consists of charted accountants associations of England and Scotland made a statement named "the model of financial reporting in future". In this statement they suggested to use a statement of gains should be added additional to the traditional income statement to report the income comprehensively.

In August 1997, International Accounting Standards Committee (IASC) modified IAS 1. Then on January 1998, IASC and four accounting standards setting institutions of U.K., U.S., Australia and Canada reached an agreement that reporting of comprehensive income in a single statement.

As for the format of comprehensive income reporting, there are three types of statement that have been widely used in the countries worldwide: two income statements, one extended statement and statement of equity.

(1) Two statements method: one income statement and one comprehensive income statement. By this method, addition to the traditional income statement, a second statement-comprehensive income statement is provided to describe the comprehensive income information. The FRS 3 "Reporting Financial Performance" released by Accounting Standards Board (ASB) of U.K. in 1992 requires enterprises to prepare a "Statement of All Recognized Gains and Losses". Similarly, FASB permits businesses to submit "comprehensive income statement" in its SFAS 130 "Reporting of Comprehensive Income". The forms of "Statement of All Recognized Gains and Losses" and "Comprehensive Income Statement" are almost the same. These statements begin with the amount of net income, include all other comprehensive income items such as foreign currency translation adjustments, minimum pension liability adjustments, and unrealized gains or losses on available-for-sale investments, and then come to the totals. This method is also 
adopted by IASC in its IAS1 (rev.), under which businesses can provide "Statement of Recognized Gains and Losses", however the total of comprehensive income is not required.

The "Comprehensive Income Statement" and "Statement of All Recognized Gains and Losses" are also called a second performance statement or the fourth statement.

(2) One income statement: one extended income statement. This method combines the two income statements: income statement and comprehensive income statement discussed above into one extended income statement - "net income and comprehensive income statement". In this extended new statement, not only net income but also other comprehensive income is reported. It holds all kinds of income, whatever realized or unrealized.

(3) Statement of changed in stockholders' equity method. This method is permitted in the accounting standards of some countries and institutions such as SFAS 130 by FASB, FRS2 by New Zealand FRS, and IAS1 (rev.) by IASC. By means of providing a statement of changes in stockholders' equity, businesses can report the information of comprehensive income. Also the total amount of comprehensive is required in this statement by all accounting standards institutions unless IASC.

Among the accounting standards setting institutions adopting comprehensive income reporting, ASB permits only a second performance statement. New Zealand permits only a statement of changes in equity. In U.S., enterprises can choose either a second performance statement, or an extended income statement or a statement of changes in stockholders' equity to meet the needs of businesses. Alternative choice is also permitted by IASC, the same as by FASB.

Whether one statement method, or two statements or statement of changes in stockholders' equity method is chosen, the goal of these reporting remains the same, that is, to report more comprehensive and useful financial performance information in order to meet the users' investment, credit, and other decision-making needs. By means of this kind of reporting, the realization principle is breakthrough, the content of the financial performance report is expanded, that part of unrealized gains and losses located in the balance sheet rather than income statement is included. It is a better form to reflect the enterprise performance in the current period, easy for the users to make economic decisions.

\section{Current performance reporting system in China}

In 2006, the new Chinese Accounting Standards (CAS) was released. According to CAS, net income based on traditional income theory is used as the major indicator of enterprise performance. The traditional income theory based on revenues-expenses perspective consists of realization principle and historical cost, leading to reporting income only realized in the current period, unrealized holding gain or losses not included. Characteristics of performance reporting system used in China now can be summarized as follows:

(1) Historical cost is the main measurement attribute. According to CAS, assets should be recorded at historical cost at the time of acquisition. In spite of price changes, except as otherwise stipulated by the state, book value should not be adjusted. As for financial instrument, some can be recorded at market value at the end of period, and unrealized holding gain or losses resulted from the fair value change such as those on available for sale securities should be disclosed in equity section of balance sheet.

(2) Revenue is recognized based on realization principle. According to the realization principle and related provisions of the accounting standards for enterprises, enterprises shall rationally recognize revenue and record income realized in time. By the accounting standards for enterprises - income of regulation, the revenues for goods sold or services rendered should be recognized when the related conditions can be met. Other gains or losses on such as revaluation of plant asset, holding gain on available for sale securities are recorded into capital reserve of balance sheet.

(3) Net income or profit is the major indicator of valuating the business performance. According to China's Company Law and the relevant regulations, most business activities such as securities issuance of stocks, suspension and supervising listed companies are valuated mainly by using the profit index. The special attention to profit in a certain extent which results in the quality of the balance sheet and reality, has become a very important problem. At present, profit is the major indicator of valuating the business performance.

\section{Advices on how to apply comprehensive income reporting in China}

As discussed above, comprehensive income reporting has not been applied in China accounting practices. But with the globalization of economy and accounting, consideration on how to apply comprehensive income reporting system should be put forward to meet the needs of rapid development of economic situation in China. Due to the immature environment of China's market economic situation, we suggest there are two steps in applying comprehensive income reporting in China.

(1) As the first step, the current statement of changes in stockholders' equity should be prepared completely, by reporting all kinds of interest changes, in which other comprehensive income items such as unrealized holding gains or losses should be included in details. Although by the new accounting standards, statement of changes in stockholders' 
equity is required to be submitted as a major statement, comprehensive incomes section has not yet be separated from other equity items. Therefore, in the first stage of applying comprehensive income reporting, as a part of comprehensive income, other comprehensive income should be reported separately from other equity items.

(2) Based on the first step, the second step is to improve the income statement into an extended income statement. That is, combine the other comprehensive income information and the current income statement into one complete statement. Then in a complete income statement all kinds of income information can be found. As known widely, the comprehensive income is companied with the use of fair value attribute. In fact, in the new accounting standard for business enterprises, the fair value measurement attribute has already been used in some standards such as debt restructuring, the exchange of non-monetary assets, and etc. The application of fair value will inevitably promote the development of comprehensive income reporting.

But at the same time the fair value is used, the reliability of the information will severely decrease. Furthermore, fair value measurement has been not fully regulated in China because of the immaturity of market, thus there may be a long way to apply comprehensive income reporting regularly in China. Anyway, by completing the two steps, the comprehensive income reporting will provide more useful and related information, and satisfy the users with comprehensive financial information in future.

\section{References}

FASB. (1997). SFAS 130, Reporting of Comprehensive Income. [Online] Available: www.fasb.org

FASB. (2006). SFAS 157, Fair Value Measurement. [Online] Available: www.fasb.org

IASC. (1998). IAS 1(rev.) Presentation of Financial Statements. [Online] Available: www.iasb.org

Ministry of Finance. Accounting Standards for Business Enterprises. (2006). Economic Science Press. Peter Walton, "the trouble with comprehensive income. Accounting and Business, Oct. 2002. 